\title{
Morphological evaluation of cardoon (Cynara cardunculus L.): assessing biodiversity for applications based on tradition, innovation and sustainability
}

\author{
P. Barracosa $\cdot$ J. Oliveira $\cdot$ M. Barros $\cdot$ E. Pires
}

\begin{abstract}
Selected cardoon cultivars established in the "Serra da Estrela" region were analysed to evaluate morphological characteristics related principally to the production of cardoon flowers, which are a compulsory ingredient for particular Mediterranean PDO cheese regions. The biodiversity of twelve cardoon cultivars installed in an experimental field were evaluated over three growing seasons using thirty-four morphological descriptors. Statistically significant differences were found between cultivars for twenty-four morphological characteristics which indicate a wide genetic diversity. The relationship among the cultivars and characteristics was analysed using principal component analysis. A three dimensional template was found to be very significant and explained $71 \%$ of the total variation. The first component is dominated positively by plant height,
\end{abstract}

diameter of stalk, inflorescence characteristics and flower production, while the second component is positively dominated by leaf characteristics. Cultivars A26, D32 and D33, present a plant architecture simultaneously well adapted for flower production, ease of harvesting and plant biomass. These characterizations and understandings can be useful for a plant breeding programme to develop cultivars for innovative potential applications besides flowers, and also for application by other cheese producers in Mediterranean regions.

Keywords Cynara cardunculus L. .

Biodiversity · Plant morphology ·

"Serra da Estrela" PDO cheese · CARDOP

\section{Introduction}

Cynara cardunculus L. (Asteraceae-Carduoideae), native to the Mediterranean basin, being a crosspollinated diploid species $(2 \mathrm{n}=2 \mathrm{x}=34)$ with proterandrous and asynchronous sexual maturity, harbours a highly heterozygous genetic background (Portis et al. 2005). The wild cardoon [var. sylvestris (Lamk) Fiori] has been recognized as the ancestor of both the globe artichoke [var. sativa Moris, var. scolymus (L.) Fiori, subsp. scolymus (L.) Hegi] and the leafy or cultivated cardoon (var. cardunculus, var. altilis DC.) (Rottenberg et al. 1996), confirmed by molecular studies (Sonnante et al. 2007). 
In Mediterranean regions, aqueous extracts from cardoon flowers have been used for centuries as coagulants in traditional ewes' milk cheese making, creating specific characteristics of texture and flavour. According to specific regulation, the use of cardoon flowers as the coagulant is compulsory for some Mediterranean cheeses varieties that have protected designations of origin (PDO) (Roseiro et al. 2005) due to their high content of aspartic proteases, and high milk-clotting activity (Veríssimo et al. 1995). Due to the wide diversity obtained in cardosin biochemical profiles it is necessary to characterize the cardoon germplasm of the "Serra da Estrela" region based on morphological, biochemical and genetic characteristics.

Nowadays, the cultivation of this crop in our region, which requires more than 1 ton/year of cardoon flowers for PDO cheese production, is an opportunity to develop flowers with standard quality. Simultaneously, it could have direct positive effects on the environment for water management, soil erosion control and improvement of soil characteristics (Grammelis et al. 2008). A restricted number of cheese artisanal factories produce their own cardoon flowers while the majority obtain cardoon flowers mainly from other origins and species not specified. For the CARDOP project a cheese artisanal producer (Casa da Insua) was selected to introduce twelve previously uncharacterized cultivars from two main fields (Ancose and DRAPC). These cardoon plants represent the genetic resources distributed in the region that have been proven in the application of cheese production. They were selected mainly because of high flower production and ease of harvesting. The flower and plant biomass production are compatible, which increases the profitability of this crop.

Cardoon is a multipurpose and versatile crop with a wide spectrum of potential applications (Fernández et al. 2006). Many studies support the important role of cardoons in human nutrition, due to its high content of nutraceutical and bio-active compounds such as inulin and antioxidant phenolics (Pandino et al. 2011). Furthermore, cardoon extracts have shown hepatoprotective, anti-tumor (Mileo et al. 2012), antibacterial and anti-HIV activity and the ability to inhibit cholesterol biosynthesis and LDL oxidation (Lattanzio et al. 2009). Cardoon can also be exploited for production of lignocellulosic biomass and seed oil (Fernández et al. 2006), production of green forage for livestock (Cajarville et al. 1999), dry biomass for energy production, raw material in paper pulp (Gominho et al. 2011) and for plywood.

The main objective of the present study was to evaluate the morphological biodiversity of forty-eight plants belonging to twelve cultivars over three growing seasons to define the suitable plant architecture for flower production and harvesting for PDO cheese producers. The potential of fresh and dry biomass and seed production to increase the profitability of this multipurpose species was also evaluated.

\section{Materials and methods}

Plant material and cultivation

Twelve cardoon cultivars were installed at Casa da Ínsua, a cheese artisanal factory in the "Serra da Estrela" region (lat. 4040'34"N; long. $7^{\circ} 42^{\prime} 25^{\prime \prime} \mathrm{W}$ ). Seven of the cultivars were sourced from Ancose (A) -Oliveira do Hospital $\left(40^{\circ} 22^{\prime} 18^{\prime \prime} \mathrm{N} ; 7^{\circ} 53^{\prime} 13^{\prime \prime} \mathrm{W}\right)$ (A1, A11, A19, A21, A25, A26, A27) and the other five (D32, D33, D34, D37, D38) were from DRAPC (D)_Viseu $\left(40^{\circ} 39^{\prime} 50^{\prime \prime} \mathrm{N} ; 7^{\circ} 54^{\prime} 11^{\prime \prime} \mathrm{W}\right)$. Field trials were conducted over three years, during 2012/2013 to 2014/2015. All plants were seed-propagated and transplanted in the field according to a randomized block experimental design with four replications, adopting a planting density of $1.0 \mathrm{plant} / \mathrm{m}^{2}$ in each plot. The experimental unit consists of four plants of each of the twelve cultivars, with four replications, in a total of 192 plants. The plantation was established on 30th January 2011. Cultivation was carried out with low input of fertilizer and manual weeding. Crop water requirements were satisfied by rain, however in the year of plantation, some irrigation was carried out to aid the establishment of the crop.

\section{Morphological traits}

Thirty-four morphological characteristics were recorded at harvest time on four individual plants per cultivar, randomly selected, in a total of 48 plants per year. The morphological traits were evaluated based on UPOV (International Union for the Protection of New Varieties of Plant) descriptors for 
cardoon with some other specific traits. The characterization and evaluation of these cultivars began in the second year after plantation. Plant height $(\mathrm{PH})$ was measured from the soil to the highest point of the plant. The total number of offshoots per plant (SN) was obtained. The tallest was selected to count the number of primary ramifications ( $\mathrm{RpN})$, which derive directly from the stalk and the secondary ramifications (RsN) considered all the others. The numbers of inflorescences on the principal stalk (INS) and the total number of inflorescences (TNI) was accounted from all offshoots of the plant. The stalk diameter at the base (SDB) was measured at $30 \mathrm{~cm}$ from the soil and the top diameter (SDT) at $15 \mathrm{~cm}$ below the main capitula. Leaves used for morphological characterization were collected at $40 \mathrm{~cm}$ from the soil. The principal and secondary inflorescences were selected to measure the largest diameter (ID) and the length (IL). In the main inflorescence, bracts from the centre were selected to measure length $(\mathrm{BrL})$, width $(\mathrm{BrW})$ and spine length $(\mathrm{BrSpL})$. For seed characterization 20 seeds (achenes) were selected from the main capitula in each plant. The total flower production (FITWg) was obtained based on dry flowers collected from all sixteen plants of each cultivar.

\section{Statistical analysis}

To analyse the diversity of the cardoon plants, all the mentioned descriptors were subject to a oneway ANOVA with a bi-factorial model, including the effects of cultivar, growing season and the interaction: $\mathrm{y}_{i j}=\mathrm{C}_{i}+\mathrm{GS}_{j}+\left(\mathrm{C}_{i}{ }^{*} G S_{j}\right)+\varepsilon_{i j}$, where $\mathrm{y}_{i j}$ is the value of the descriptor $i$ in the growing season $j, \mathrm{C}_{i}-$ cultivar $i$, GS - growing season $j,\left(\mathrm{C}_{i}{ }^{*} \mathrm{GS}_{j}\right)$ - cultivar* growing season interaction and $\varepsilon_{i j}$-error. Differences of means were analyzed with Tukey's post hoc tests. The mean squares from the ANOVA tables were extracted and the partial variance regarding each of the factors (cultivar, growing season and their interaction) and the residues were calculated, providing the relative influence $(\%)$ of each of the factors in the descriptors. All these analyses were implemented with the SPSS v. 23.0 statistical package, with a level of significance $(\alpha)$ of 0.05 .

Thirty-four morphological continuous characters were used in the multivariate analysis. The characters were standardized before carrying out the correlation and the average taxonomic distance analysis among cultivars. A principal component analysis (PCA) which employed the DCENTER and EIGEN procedures was performed. The two first principal coordinates were used to produce a two-dimensional scatter plot to understand how each axis influenced the variation among cultivars and which morphological characteristics are determinants for their discrimination. All computations for multivariate analysis were carried out using the NTSYS-pc version 2.1 software (Rohlf 2000).

\section{Results}

Morphological analysis

The general analysis of the morphological characteristics related to flower production and ease of harvesting considered plant height, stalk diameter, numbers of offshoots, ramifications and inflorescences and dimensions of spines.

\section{Plant height}

Plant height $(\mathrm{PH})$ averaged for all cultivars and factors was $215.5 \mathrm{~cm}$. PH showed an increase over the years (Table 1) and a significant variance between cultivars (Table 2). Cultivars D34 and D37 showed the highest average values and cultivars A11, A19 and A25 the lowest (Table 2).

\section{Number of offshoots}

The average number of offshoots (SN) per plant was 4.4 which increased from 3.6 to 5.1 (Table 1). Cultivars A25, A27 and D34 showed the highest average values $(>5)$ and cultivars A19 and D33 the lowest $(<4)$ (Table 2). SN showed a significant variation between growing seasons (Table 3).

\section{Number of ramifications}

The number of ramification was discriminated in primary $(\mathrm{RpN})$ and secondary ramifications (RsN). $\mathrm{RpN}$ averaged for cultivars and years was 4.3 and RsN 8.3. Cultivars A1 and D32 showed the highest average values $(>10)$ and A21 the lowest $(<6)$ (Table 2). RpN presented significant differences, 
Table 1 List of plant descriptors used for the morphological characterization of cardoon

\begin{tabular}{|c|c|c|c|c|}
\hline Plant descriptor & Code & $2012-13$ & 2013-14 & $2014-15$ \\
\hline 1. Plant height $(\mathrm{cm})$ & $\mathrm{PH}$ & $210.7 \pm 39.3^{\mathrm{b}}$ & $210.5 \pm 35.6^{\mathrm{a}}$ & $224.8 \pm 33.9^{\mathrm{b}}$ \\
\hline 2. Stems number & $\mathrm{SN}$ & $3.6 \pm 1.3^{\mathrm{a}}$ & $4.4 \pm 1.7^{\mathrm{a}}$ & $5.1 \pm 2.0^{\mathrm{b}}$ \\
\hline 3. Primary ramifications number & $\mathrm{RpN}$ & $4.5 \pm 1.1$ & $3.8 \pm 1.1$ & $4.6 \pm 1.6$ \\
\hline 4. Secondary ramifications number & $\mathrm{RsN}$ & $13.0 \pm 7.7^{\mathrm{b}}$ & $6.9 \pm 5.2^{\mathrm{a}}$ & $5.0 \pm 4.1^{\mathrm{a}}$ \\
\hline 5. Total inflorescences number & TNI & $45.4 \pm 23.1$ & $32.0 \pm 17.6$ & $37.4 \pm 19.9$ \\
\hline 6. Inflorescences number on the stem & INS & $18.5 \pm 8.3^{\mathrm{b}}$ & $11.1 \pm 5.8^{\mathrm{a}}$ & $10.8 \pm 5.1^{\mathrm{a}}$ \\
\hline 7. Lowest primary ramification $(\mathrm{cm})$ & $\mathrm{PrH}$ & $115.6 \pm 39.0^{\mathrm{a}}$ & $123.9 \pm 43.3^{\mathrm{a}}$ & $155.5 \pm 31.5^{\mathrm{b}}$ \\
\hline 8. Diameter stalk on the top (mm) & SDT & $12.2 \pm 3.1^{\mathrm{b}}$ & $11.4 \pm 1.3^{\mathrm{b}}$ & $10.3 \pm 1.9^{\mathrm{a}}$ \\
\hline 9. Diameter stalk on the base (mm) & SDB & $35.4 \pm 9.0^{\mathrm{b}}$ & $30.4 \pm 7.1^{\mathrm{a}}$ & $29.3 \pm 7.8^{\mathrm{a}}$ \\
\hline 10. Spine length (mm) & $\mathrm{SpL}$ & $5.3 \pm 5.6$ & $4.2 \pm 4.8$ & $5.0 \pm 5.8$ \\
\hline 11. Leaf length $(\mathrm{cm})$ & LL & $96.4 \pm 15.2^{\mathrm{b}}$ & $79.3 \pm 13.9^{\mathrm{a}}$ & $83.1 \pm 20.0^{\mathrm{a}}$ \\
\hline 12. Leaf width $(\mathrm{cm})$ & LW & $41.0 \pm 8.7$ & $39.8 \pm 6.8$ & $35.9 \pm 8.7$ \\
\hline 13. Primary lobe length $(\mathrm{cm})$ & $\mathrm{LpL}$ & $25.1 \pm 4.3^{\mathrm{b}}$ & $21.9 \pm 4.5^{\mathrm{a}}$ & $20.1 \pm 4.9^{\mathrm{a}}$ \\
\hline 14. Primary lobe width $(\mathrm{cm})$ & $\mathrm{LpW}$ & $10.5 \pm 3.0$ & $10.1 \pm 3.1$ & $8.7 \pm 2.6$ \\
\hline 15. Secondary lobe length $(\mathrm{cm})$ & LsL & $10.3 \pm 3.7^{\mathrm{b}}$ & $9.0 \pm 2.8^{\mathrm{b}}$ & $6.0 \pm 1.6^{\mathrm{a}}$ \\
\hline 16. Secondary lobe width $(\mathrm{cm})$ & LsW & $2.0 \pm 0.6^{\mathrm{b}}$ & $1.7 \pm 0.4^{\mathrm{a}}$ & $1.4 \pm 0.6^{\mathrm{a}}$ \\
\hline 17. Petiole width (mm) & LPtW & $14.0 \pm 4.1^{\mathrm{b}}$ & $12.1 \pm 3.3^{\mathrm{ab}}$ & $11.0 \pm 3.8^{\mathrm{a}}$ \\
\hline 18. Petiole thickness (mm) & LPtT & $15.9 \pm 3.0^{\mathrm{b}}$ & $13.6 \pm 3.2^{\mathrm{a}}$ & $12.5 \pm 3.9^{\mathrm{a}}$ \\
\hline 19. Petiole spine length (mm) & LPtSpL & $4.0 \pm 4.0$ & $3.3 \pm 3.8$ & $3.7 \pm 3.8$ \\
\hline 20. Leaf weight (g) & $\mathrm{LWg}$ & $99.1 \pm 42.6^{\mathrm{b}}$ & $60.6 \pm 42.9^{\mathrm{a}}$ & $44.8 \pm 23.1^{\mathrm{a}}$ \\
\hline 21. Lobe weight (g) & $\mathrm{LbWg}$ & $3.0 \pm 1.3^{\mathrm{b}}$ & $2.2 \pm 1.6^{\mathrm{ab}}$ & $2.0 \pm 0.8^{\mathrm{a}}$ \\
\hline 22. Petiole weight (g) & LPtWg & $53.8 \pm 26.2^{\mathrm{b}}$ & $32.2 \pm 27.7^{\mathrm{a}}$ & $25.6 \pm 15.8^{\mathrm{a}}$ \\
\hline 23. Inflorescence principal length (mm) & IpL & $56.4 \pm 10.7^{\mathrm{a}}$ & $68.0 \pm 7.4^{\mathrm{b}}$ & $59.1 \pm 6.8^{\mathrm{a}}$ \\
\hline 24. Inflorescence principal diameter (mm) & $\mathrm{IpD}$ & $59.1 \pm 14.7^{\mathrm{a}}$ & $69.3 \pm 8.3^{\mathrm{b}}$ & $64.5 \pm 8.4^{\mathrm{ab}}$ \\
\hline 25. Bract length (mm) & $\mathrm{BrL}$ & $28.2 \pm 5.4^{\mathrm{b}}$ & $21.5 \pm 4.1^{\mathrm{a}}$ & $19.7 \pm 3.4^{\mathrm{a}}$ \\
\hline 26. Bract width (mm) & $\mathrm{BrW}$ & $11.8 \pm 3.5^{\mathrm{a}}$ & $13.2 \pm 2.0^{\mathrm{b}}$ & $12.1 \pm 1.8^{\mathrm{ab}}$ \\
\hline 27. Bract spine length (mm) & BrSpL & $2.8 \pm 1.6^{\mathrm{a}}$ & $2.9 \pm 1.4^{\mathrm{a}}$ & $7.1 \pm 5.2^{\mathrm{b}}$ \\
\hline 28. Inflorescence secondary length (mm) & IsL & $50.6 \pm 9.0^{\mathrm{a}}$ & $61.5 \pm 7.9^{\mathrm{b}}$ & $53.0 \pm 5.1^{\mathrm{a}}$ \\
\hline 29. Inflorescence secondary diameter $(\mathrm{mm})$ & IsD & $49.9 \pm 13.9^{\mathrm{a}}$ & $60.0 \pm 8.4^{\mathrm{b}}$ & $54.4 \pm 7.3^{\mathrm{a}}$ \\
\hline 30. Seed length (mm) & SdL & $7.39 \pm 0.56$ & $7.54 \pm 0.41$ & $7.25 \pm 0.50$ \\
\hline 31. Seed width (mm) & SdW & $3.44 \pm 0.36^{\mathrm{a}}$ & $3.60 \pm 0.27^{\mathrm{ab}}$ & $3.48 \pm 0.35^{\mathrm{b}}$ \\
\hline 32. Seed thickness (mm) & $\mathrm{SdT}$ & $2.49 \pm 0.21^{\mathrm{a}}$ & $2.65 \pm 0.21^{\mathrm{b}}$ & $2.62 \pm 0.19^{b}$ \\
\hline 33. Seed weight (g) & SdWg & $0.046 \pm 0.007$ & $0.047 \pm 0.006$ & $0.044 \pm 0.007$ \\
\hline 34. Flower total production (g) & FlTWg & $301.3 \pm 88.9^{\mathrm{b}}$ & $265.4 \pm 51.8^{\mathrm{b}}$ & $197.1 \pm 43.4^{\mathrm{a}}$ \\
\hline
\end{tabular}

Means, standard deviations and results of Duncan's multiple range test at the $5 \%$ level of 34 characters observed in three growing seasons

Values followed by the same letter in each row are not significantly different at $P<0.05$

* The differences is obtained by Tukey post hoc tests following unifactorial models

simultaneously, between cultivars and growing seasons while RsN just between years (Table 3).

\section{Stalk diameter}

The stalk diameter was analysed simultaneously at the base and the top. The average value of stalk diameter at the base (SDB) was $31.7 \mathrm{~mm}$ and at the 


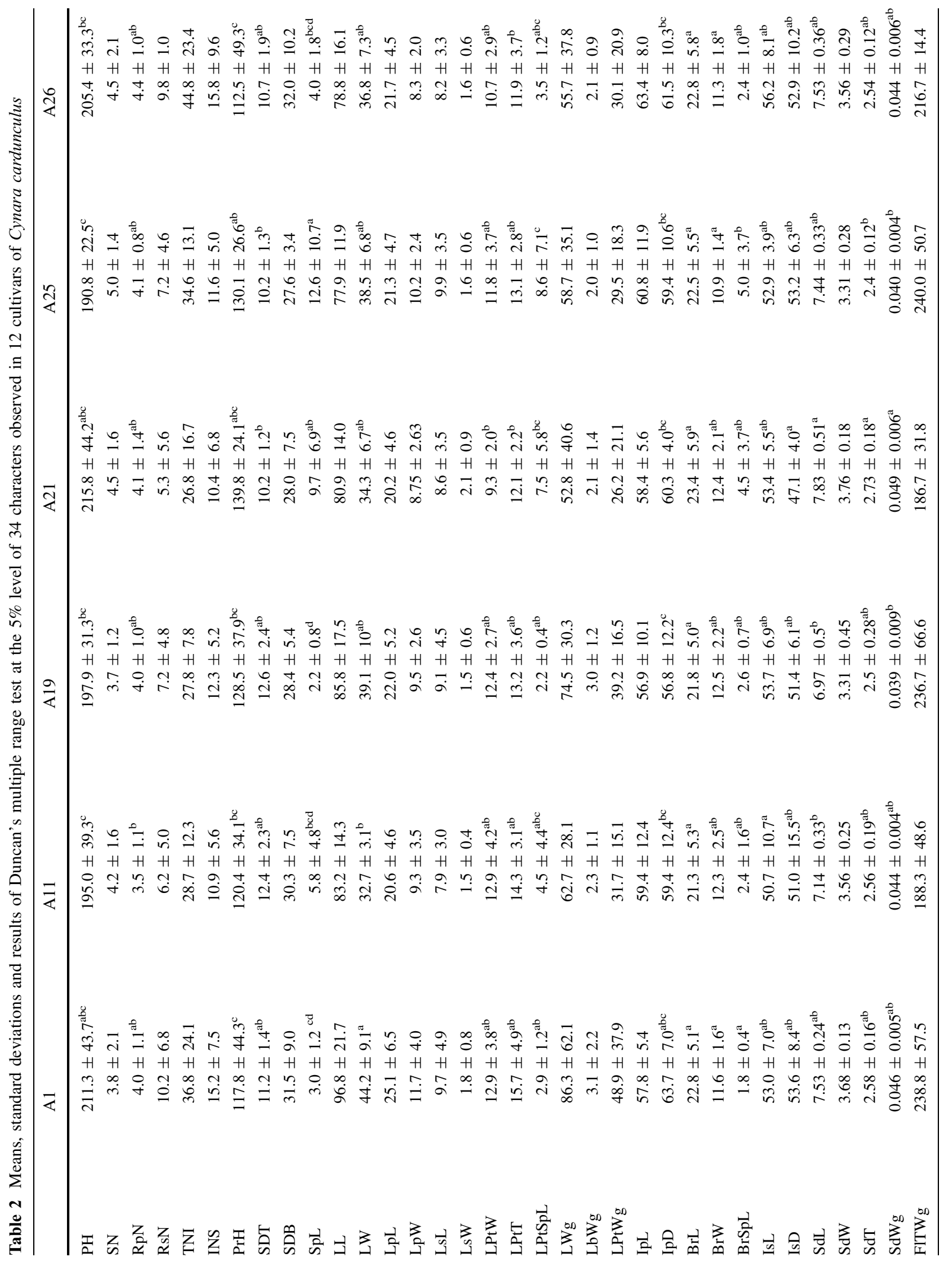




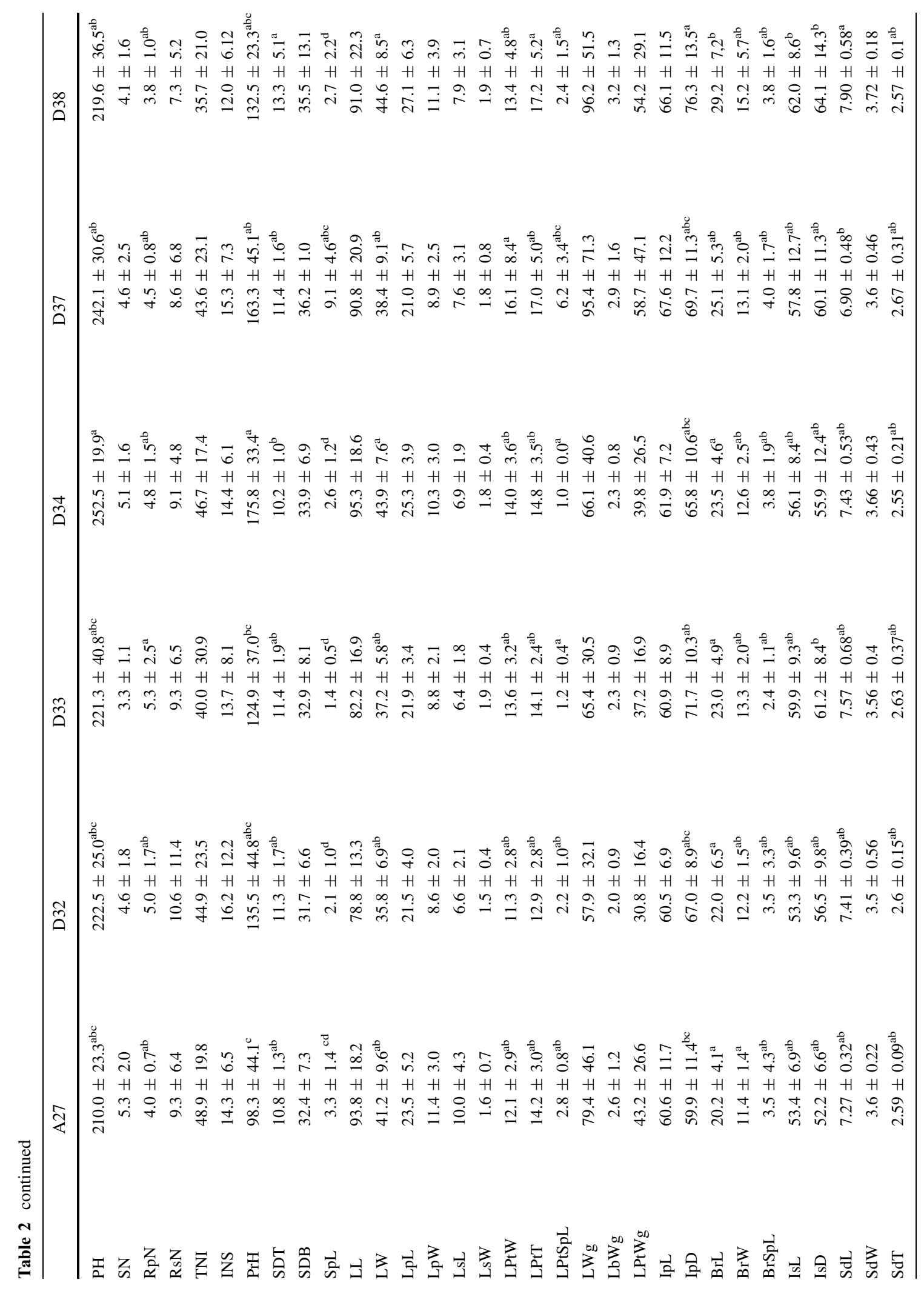


top (SDT) was $11.3 \mathrm{~mm}$. Cultivars D37 and D38 showed the highest average SDB values $(>35 \mathrm{~mm})$ and A19, A21 and A25 the lowest $(<30 \mathrm{~mm})$ (Table 2). SDT presented significant differences, simultaneously, for growing seasons and cultivars and SDB showed significant differences only for growing seasons (Table 3 ).

\section{Number of inflorescences}

The number of inflorescences, which relates directly to the number of ramifications, was discriminated by the total number of the inflorescences on the plant (TNI) and the number of inflorescences in the main stem (INS). TNI averaged over cultivars and growing seasons, was 38.3 and INS was 13.5. Cultivars A26, A27, D32, D33, D34 and D37 showed the highest TNI average values ( $>40)$ and A11, A19 and A21 the lowest $(<30)$ (Table 2). TNI presented significant differences between growing seasons (Table 3 ).

\section{Spines}

Spines were evaluated on the stems $(\mathrm{SpL})$, petioles of the leaves (LPtSp) and on the bracts of the inflorescence $(\mathrm{BrSpL})$, all these are closely related. $\mathrm{SpL}$ averaged over cultivars and growing seasons, was $4.9 \mathrm{~mm}$. Cultivars A21, A25 and D37 showed the highest average values and A1, A19, D33 and D34 the lowest (Table 2). SpL presented significant differences between cultivars (Table 3 ).

Principal component analysis

An acceptable solution for principal component analysis (PCA) was reached when three dimensions of the model were found to be significant and explain $71 \%$ of the total variance (Table 4). The first component (PC1), accounting for 39\% of the total variation, was dominated positively by the plant characteristics ( $\mathrm{PH}, \mathrm{PrH}, \mathrm{SDB})$, inflorescence characteristics (IpL, IpDBrL, BrW) and total flower production (FlTWg). PC1 was negatively dominated by leaf and seed characteristics. The second component (PC2), accounting for $19 \%$ of the total variation was dominated positively by $\mathrm{RsN}, \mathrm{LbWg}$ and $\mathrm{LPtWg}$, and negatively by spine length (SpL; LPtSpL) (Table 4; Fig. 1). 
Table 3 Analysis of variance of the genotype

\begin{tabular}{|c|c|c|c|c|c|c|c|}
\hline & \multicolumn{4}{|c|}{ Mean squares $(\%)$} & \multicolumn{3}{|c|}{ Level of significance } \\
\hline & Cultivar (C) & Growing Season (GS) & Interaction $\left(\mathrm{C}^{*} \mathrm{GS}\right)$ & Error & $\mathrm{C}$ & GS & $\left(\mathrm{C}^{*} \mathrm{GS}\right)$ \\
\hline PH & 42.8 & 34.4 & 10.8 & 11.9 & $* * *$ & ns & ns \\
\hline $\mathrm{SN}$ & 12.8 & 71.4 & 8.1 & 7.6 & ns & $* * *$ & ns \\
\hline $\mathrm{RpN}$ & 21.8 & 56.4 & 10.6 & 11.3 & $*$ & $* *$ & ns \\
\hline $\mathrm{RsN}$ & 3.6 & 87.9 & 5.1 & 3.4 & ns & $* * *$ & ns \\
\hline TNI & 19.6 & 59.4 & 10.4 & 10.6 & ns & $* *$ & ns \\
\hline INS & 4.5 & 86.4 & 5.3 & 3.8 & ns & $* * *$ & ns \\
\hline $\operatorname{PrH}$ & 18.3 & 73.1 & 5.0 & 3.7 & $* * *$ & $* * *$ & ns \\
\hline SDT & 18.8 & 67.9 & 6.9 & 6.4 & $* * *$ & $* * *$ & ns \\
\hline SDB & 12.9 & 70.3 & 8.0 & 8.7 & ns & $* * *$ & ns \\
\hline $\mathrm{SpL}$ & 79.8 & 8.3 & 0.9 & 11.1 & $* * *$ & ns & ns \\
\hline LL & 11.6 & 77.7 & 5.8 & 4.9 & $*$ & $* * *$ & ns \\
\hline LW & 29.4 & 56.1 & 4.7 & 9.8 & $* *$ & $* *$ & ns \\
\hline LpL & 11.7 & 80.1 & 2.7 & 5.5 & $*$ & $* * *$ & ns \\
\hline $\mathrm{LpW}$ & 19.3 & 61.9 & 6.4 & 12.3 & ns & $* *$ & ns \\
\hline LsL & 5.3 & 88.1 & 4.0 & 2.5 & $*$ & $* * *$ & ns \\
\hline LsW & 5.4 & 83.9 & 4.4 & 6.2 & ns & $* * *$ & ns \\
\hline LPtW & 17.6 & 66.4 & 7.0 & 9.0 & $*$ & $* * *$ & ns \\
\hline LPtT & 14.5 & 75.1 & 4.7 & 5.7 & $* *$ & $* * *$ & ns \\
\hline LPtSpL & 74.1 & 6.6 & 1.6 & 17.7 & $* * *$ & ns & ns \\
\hline LWg & 6.0 & 88.5 & 2.3 & 3.1 & $*$ & $* * *$ & ns \\
\hline $\mathrm{LbWg}$ & 13.5 & 72.2 & 6.6 & 7.8 & ns & $* * *$ & ns \\
\hline LPtWg & 9.5 & 82.8 & 3.5 & 4.2 & $*$ & $* * *$ & ns \\
\hline IpL & 6.1 & 86.5 & 4.3 & 3.1 & $*$ & $* * *$ & ns \\
\hline IpD & 22.8 & 68.3 & 3.6 & 5.3 & $* * *$ & $* * *$ & $\mathrm{~ns}$ \\
\hline BrL & 5.9 & 91.7 & 0.9 & 1.6 & $* * *$ & $* * *$ & ns \\
\hline $\mathrm{BrW}$ & 28.4 & 51.4 & 9.3 & 10.9 & $* *$ & $*$ & $\mathrm{~ns}$ \\
\hline $\mathrm{BrSpL}$ & 12.7 & 76.9 & 8.1 & 2.3 & $* * *$ & $* * *$ & $* * *$ \\
\hline IsL & 7.5 & 87.3 & 2.2 & 3.1 & $*$ & $* * *$ & ns \\
\hline IsD & 18.0 & 71.8 & 4.1 & 6.1 & $* *$ & $* * *$ & ns \\
\hline $\mathrm{SdL}$ & 36.9 & 46.0 & 7.9 & 9.3 & $* * *$ & $* *$ & $\mathrm{~ns}$ \\
\hline $\mathrm{SdW}$ & 17.1 & 60.8 & 12.9 & 9.3 & ns & $* *$ & ns \\
\hline SdT & 14.4 & 69.6 & 10.8 & 5.2 & $* *$ & $* * *$ & $*$ \\
\hline SdWg & 33.2 & 47.7 & 11.9 & 7.1 & $* * *$ & $* *$ & ns \\
\hline FlTWg $^{\mathrm{a}}$ & 18.4 & 76.6 & 5.0 & - & $* * *$ & $* * *$ & - \\
\hline
\end{tabular}

MS (means squares of treatment). Statistical significance of cultivar, growing season and their interaction on the morphological traits

$* P<0.05 ; * * P<0.01, * * *<0.001$, ns no significant differences

${ }^{\text {a }}$ The level of significance is obtained by ANOVA unifactorial models

Principal component and cluster analysis discriminated the 12 cultivars into four main clusters (I-IV) (Fig. 1), using the first two principal components which accounted about $58 \%$ of the total variability among cardoon cultivars. Cluster I placed in the upper left quadrant contained cultivars A1, A19 and 
Table 4 Factor loadings for each variable on the components of PCA analysis

\begin{tabular}{|c|c|c|c|}
\hline Variables & PC1 & PC2 & PC3 \\
\hline PH & 0.78 & 0.06 & 0.37 \\
\hline SN & 0.17 & -0.53 & 0.34 \\
\hline $\mathrm{RpN}$ & 0.31 & 0.09 & 0.73 \\
\hline RsN & 0.17 & 0.60 & 0.71 \\
\hline TIN & 0.44 & 0.25 & 0.75 \\
\hline INS & 0.25 & 0.48 & 0.76 \\
\hline PrH & 0.66 & -0.35 & 0.07 \\
\hline SDT & 0.19 & 0.43 & -0.63 \\
\hline SDB & 0.82 & 0.41 & 0.21 \\
\hline $\mathrm{SpL}$ & -0.21 & -0.70 & -0.05 \\
\hline LL & 0.37 & 0.56 & -0.17 \\
\hline LW & 0.47 & 0.52 & -0.21 \\
\hline $\mathrm{LpL}$ & -0.77 & 0.45 & 0.01 \\
\hline $\mathrm{LpW}$ & -0.81 & 0.37 & -0.08 \\
\hline LsL & -0.91 & 0.06 & -0.14 \\
\hline LsW & -0.78 & 0.05 & -0.05 \\
\hline LPtW & -0.67 & 0.50 & 0.11 \\
\hline LPtT & -0.78 & 0.55 & -0.12 \\
\hline LPtSpL & -0.48 & -0.67 & -0.10 \\
\hline LWg & -0.40 & 0.81 & -0.23 \\
\hline LbWg & -0.55 & 0.71 & -0.30 \\
\hline LPtWg & -0.19 & 0.87 & -0.14 \\
\hline IpL & 0.79 & -0.05 & 0.15 \\
\hline IpD & 0.76 & 0.33 & 0.03 \\
\hline $\mathrm{BrL}$ & 0.74 & 0.04 & -0.42 \\
\hline $\mathrm{BrW}$ & 0.70 & 0.17 & -0.45 \\
\hline $\mathrm{BrSpL}$ & -0.25 & -0.52 & 0.21 \\
\hline IsL & 0.77 & 0.24 & -0.09 \\
\hline IsD & 0.76 & 0.41 & 0.01 \\
\hline SdL & -0.82 & 0.04 & 0.37 \\
\hline $\mathrm{SdW}$ & -0.76 & 0.06 & 0.40 \\
\hline SdT & -0.69 & 0.11 & 0.44 \\
\hline $\mathrm{SdWg}$ & -0.51 & 0.22 & 0.50 \\
\hline FlTWg & 0.83 & 0.27 & 0.06 \\
\hline Eigen values & 13 & 7 & 4 \\
\hline$\%$ of variance & 39 & 19 & 13 \\
\hline Cumulative $\%$ of variance & 39 & 58 & 71 \\
\hline
\end{tabular}

Factor loadings $>10.61$ are in bold

A27. Cluster II in the lower quadrant included cultivars A11, A21 and A25. Cluster III placed in the centre comprised cultivars A26, D32 and D33 and cluster IV on the right of the projection presented the cultivars D34, D37 and D38.

\section{Discussion}

Morphological and physiological characters have been traditionally used for the identification of cardoon genotypes, cultivars, landraces and ecotypes (Lahoz et al. 2011; Ben Ammar et al. 2014). This morphological analysis on cardoon plants evaluated on a 3-year study showed that twenty-four quantitative morphological characteristics differed significantly among the cultivars and just three characteristics, namely $\mathrm{PH}, \mathrm{SpL}$ and $\mathrm{LPtSpL}$ were not influenced by growing seasons. The plant characteristics $\mathrm{PH}, \mathrm{PrH}$ and SN showed an increase along this study. On the contrary, SDB, SDT, RsN and INS showed a decrease in the same period. It means that along the years, the number of stems increases and the predominance of the main stem over the others were reduced.

Plant height $(\mathrm{PH})$ presented a significant variance among cultivars but not between growing seasons. In other studies, PH was affected mainly by year of cultivation (73.2\% of total variation) while ecotype effect accounted 18.2\% (Raccuia and Melilli 2007). According to Lahoz et al. (2011), PH showed simultaneously significant differences between cultivar and growing season. These results were probably obtained because the plant height was modest, the rainfall was irregular along those studies and the characterization started in the first year of plantation, when the aboveground biomass production is usually low (Fernández et al. 2006).

The number of offshoots ( $\mathrm{SN}$ ) showed significant variations between growing seasons but not cultivars, as was obtained by Lahoz et al. (2011). Raccuia and Melilli (2007) found a clear influence of the growing season $(97.7 \%)$ and just $1.3 \%$ for the ecotype. Ierna and Mauricaule (2010) reported that in the successive years, cardoon plants were better established and the number of offshoots increased in all cultivars, reaching values of five in the third year. In general, some cultural practices to control the total number of offshoots per plant should be implemented, because a higher number of stems by plant, may not be associated with an increase of the total plant biomass and flower production. 


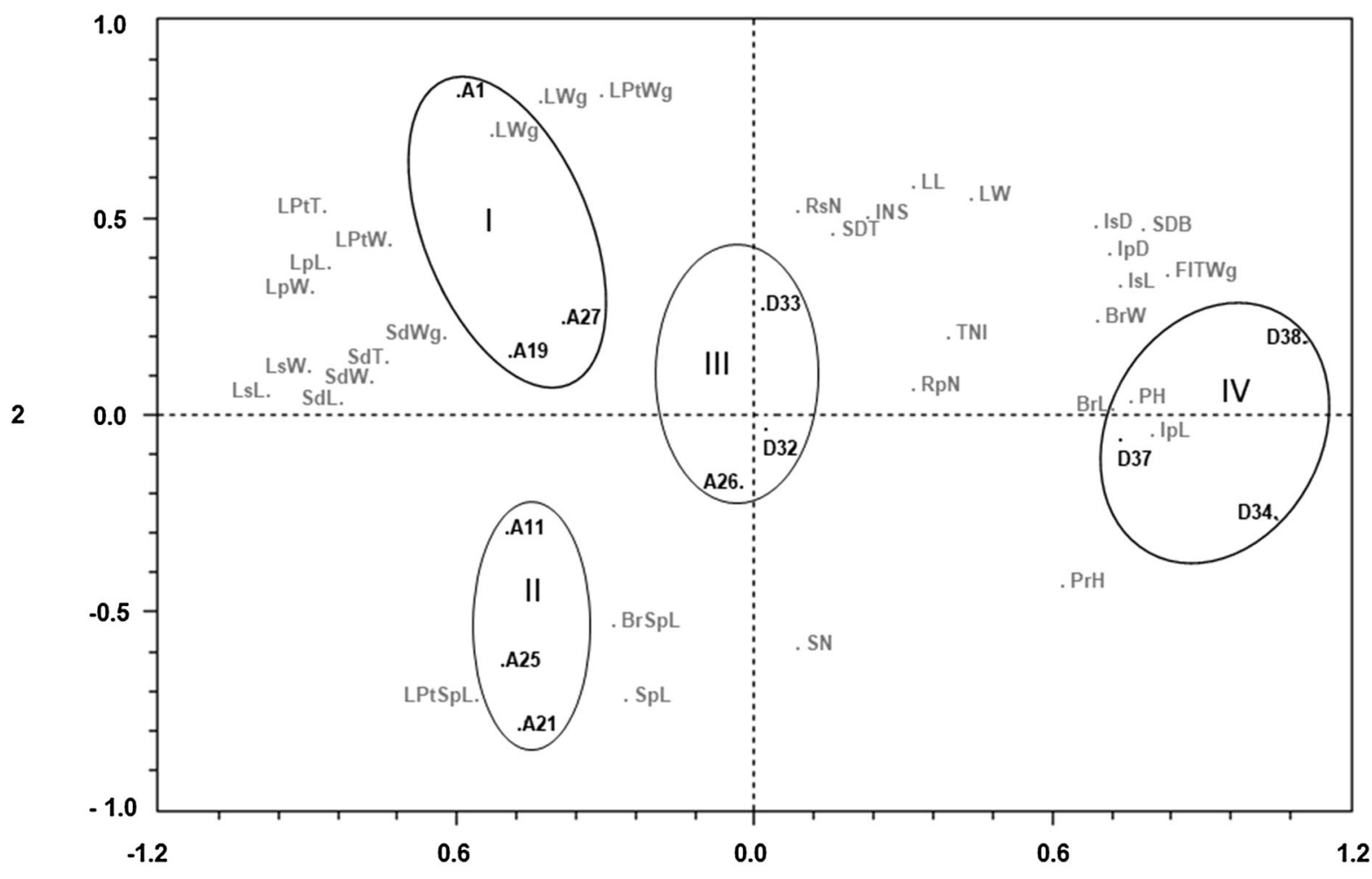

Fig. 1 Projection of the twelve cultivars based on the average results of thirty-four morphological characteristics along three growing seasons in the plan defined by the principal

Both stalk diameter characteristics (SDT; SDB) which showed a reduction along the study revealed a high contribution of growing season $(\approx 70 \%)$. However the stalk diameter at the top (SDT) also showed significant variation between cultivars. These results are probably related to the increase of the stem numbers per plant.

This study evaluated the number of primary $(\mathrm{RpN})$ and secondary ramifications (RsN) which has rarely been considered in previous studies (Ben Ammar et al. 2014). RsN revealed significant differences between growing seasons, probably because of the large variation observed, specially comparing the first year with those following. The RsN which relates directly to the number of inflorescences (TNI) and the total flower production (FlTWg) was the characteristic most influenced by the growing season.

Spine length (SpL) was the characteristic most influenced by the cultivar and least influenced by the growing season. In this study, despite the majority of

\section{1}

components 1-2. Projection of the thirty-four morphological characteristics (grey) in the plan defined by the principal components $1-2$

the plants evaluated having short spines, three classes of spine length were considered ( $<5 \mathrm{~mm} ; 5-20 \mathrm{~mm}$; $>20 \mathrm{~mm}$ ). This result seems not to accord with a trait controlled by a single gene with two alternative alleles as proposed by Basnizki and Zohary (1994).

The wide distribution of the cardoon cultivars obtained by the PCA projection showed that an extensive biodiversity was well discriminated by a set of quantitative traits. On the projection all cultivars from Ancose (A) are in the left quadrants and those from DRAPC (D) in the right quadrants. It could mean that the cardoon genetic resources, selected for these fields, were probably derived from distinct origins. Comparing cultivar's provenances, namely from Ancose and DRAPC, significant statistical differences were obtained in the majority of the characteristics. All characteristics, except spine length $(\mathrm{SpL})$, presented higher mean values in the cultivars obtained from DRAPC (D) compared with those from Ancose (A) and the coefficients of variation were 
quite similar for each characteristic from both origins (data not shown). The cardoon genetic resources for the "Serra da Estrela" region, mainly selected for flower production, could produce a plant architecture with a height of $2 \mathrm{~m}$, a number of primary and secondary ramifications to provide more than 20 inflorescences per stem and a total of 50 inflorescences in 3-4 stems per plant. The plant should present no or few spines to facilitate harvesting.

\section{Conclusions}

This extensive characterization on cardoon biodiversity from the "Serra da Estrela" region confirmed the interest in promoting cardoon plants as endogenous resources suitable for the development of perennial cultivation systems with low input. The main focus would be the production of flowers, which are one of the compulsory ingredients for the identity and exclusivity of PDO "Serra da Estrela" cheese production. To respect the regulations, cardoon flowers should be produced in the PDO region. The fresh and dried plant biomass production as well as the seed yield could complement the flower production for the global valuation of this crop. This concept may be applied to all Portuguese and Spanish regions that use cardoon flowers for cheese production, not just to preserve and improve the quality of the cheese, but also the landscapes and ecosystems of these territories. This innovative project (CARDOP) allowed selfproduction of flowers for one of the main cheese producers in the Serra da Estrela region (Casa da Insua) which is being promoted as a successful example for others. The cultivars well adapted for PDO "Serra da Estrela" cheese, should be propagated by in vitro multiplication to assure plants with those characteristics for production and harvesting of flowers with standard high quality. Cardoon biomass due its characteristics should be also used for innovative purposes, with future applications on food nutrition and nutraceuticals, health and cosmetics, plant protection and new environmental friendly materials currently under investigation.

Acknowledgements This work was supported by the project PRODER-18648-02009975 (1/01/2011-31/03/2015). We would like to thank José Matias (Casa da Insua), João Madanelo (Ancose) and António Figueiredo (APPACDM) for all the support to develop this work. The authors are grateful to Jimmy Shadbolt for the final linguistic revision.

\section{Compliance with ethical standards}

Conflict of interest The authors declare that they have no conflict of interest.

\section{References}

Basnizki Y, Zohary D (1994) Breeding of seed-planted artichoke. In: Janick J (ed) Plant breeding reviews, vol 12. Wiley, New York, pp 253-269

Ben Ammar I, Harzallah-Skhiri F, Al Mohandes Dridi B (2014) Morphological variability of wild cardoon (Cynara cardunculus L. var. sylvestris) Populations in North of Tunisia. ISRN Agronomy 2014, 9, Article ID 656937

Cajarville C, González J, Repetto JL, Rodríguez CA, Martínez A (1999) Nutritive value of green forage and crop byproducts of Cynara cardunculus. Ann Zootech 48:353365

Fernández J, Curt MD, Aguado PL (2006) Industrial application of Cynara cardunculus L. for energy and other uses. Ind Crop Prod 24:222-229

Gominho J, Lourenço A, Palma P, Lourenço ME, Curt MD, Fernández J, Pereira H (2011) Large scale cultivation of Cynara cardunculus L. for biomass production-a case study. Ind Crops Prod 33:1-6

Grammelis P, Malliopoulou A, Basinas P, Danalatos NG (2008) Cultivation and characterization of Cynara cardunculus for solid biofuels production in the mediterranean region. Int J Mol Sci 9(7):1241-1258

Ierna A, Mauromicale G (2010) Cynara cardunculus L. cultivars as a crop for energy purposes in a Mediterranean environment. Biomass Bioenergy 34:754-760

Lahoz I, Fernández JA, Migliaro D, Macua JI, Egea-Gilabert C (2011) Using molecular markers, nutritional traits and field performance data to characterize cultivated cardoon germplasm resources. Sci Hortic 127(3):188-197

Lattanzio V, Kroon PA, Linsalata V, Cardinali A (2009) Globe artichoke: a functional food and a source of nutraceutical ingredients. J Funct Foods 1:131-144

Mileo AM, Di Venere D, Linsalata V, Fraioli R, Miccadei S (2012) Artichoke polyphenols induce apoptosis and decrease the invasive potential of the human breast cancer cell line MDAMB231. J Cell Physiol 227:3301-3309

Pandino G, Lombardo S, Mauromicale G, Williamson G (2011) Phenolic acids and flavonoids in leaf and floral stem of cultivated and wild Cynara cardunculus L. cultivars. Food Chem 126:417-422

Portis E, Mauromicale G, Barchi L, Mauro R, Lanteri S (2005) Population structure and genetic variation in autochthonous globe artichoke germplasm from Sicily Island. Plant Sci 168:1591-1598

Raccuia SA, Melilli MG (2007) Biomass and grain oil yields in Cynara cardunculus L. cultivars grown in a Mediterranean environment. Field Crops Res 101:187-197 
Rohlf FJ (2000) NTSYSpc-Numerical taxonomy and multivariate analysis system (version 2.1). Exeter Software, Setauket, New York

Roseiro LB, Viala D, Besle JM, Carnat A, Fraisse D, Chezal JM, Lamaison JL (2005) Preliminary observations of flavonoid glycosides from the vegetable coagulant Cynara L. in protected designation of origin cheeses. Int Dairy J 15:579-584

Rottenberg A, Zohary D, Nevo E (1996) Isozyme relationships between cultivated artichoke and the wild relatives. Genet Resour Crop Evol 43:59-62
Sonnante G, Pignone D, Hammer K (2007) The domestication of artichoke and cardoon: from Roman times to the genomic age. Ann Bot 100:1095-1100

Veríssimo P, Esteves CL, Faro CJ, Pires EV (1995) The vegetable rennet of Cynara cardunculus L. contains two proteinases with chymosin and pepsin-like specificities. Biotechnol Lett 17:621-626 